\title{
SHERI SPAINE LONG
}

\section{Poor Bea}

(Traducción de la obra de Francisco Zamora Loboch)

The Grove 15 (2008)

Poor Bea. I no longer even remember the contours of her face. There was a time when I could not take my eyes off the soft magical pout that perfected her lower lip, slightly prominent, and the tiny tongue peering through it, profoundly red.

This morning, when I heard the news at the Rubio, the weather outside was exactly like the day we met. By then, Madrid had already begun its unforgiveable road toward chaos. The birds, with their contaminated lungs, damaged by the lethal suffocation of exhaust fumes, evicted from the parks and the neighborhoods by an irrational army of ferocious bulldozers, cranes and backhoes, were beginning to undergo the same slow agony brought on by every onslaught of winter.

- Madrid is not a city for birds.

That phrase of hers, which I never understood in its entirety, now acquires its true meaning. I heard it for the first time on our third walk through Ventillas, when some children armed with slingshots and BB guns shot down a sparrow that ended up falling right at Bea's feet. I felt the chill run through that fragile body. It was a kind of warning, a premonition.

By that time, Bea was living only two metro stops up from me. She had just lost that mulatto child that cried only in the early morning and scarcely, if at all, did she remember his father-Barbas. Everything happened quickly between us, hastened by a minor struggle in which neither of us lost anything more than a little modesty. And because it had been a while since we had both been feverishly looking for an attachment that could rid us of the loneliness of Africans lost in the big city, we signed a sort of pact that would insure coexisting in the kindest manner possible, since we intuited from the beginning that for us, normal cohabitation would be impossible. I left my boarding house, and she left the apartment that she shared with Mabel and Virtudes, and we took a room in a communal living space on Betanzos. 
Now I see that Bea was no different than the birds. Born to enjoy the immensity of the forests and the bounty of the elements, she routinely began a sort of accelerated shrinking every time winter poked its ears through the gap around the door. And it was of no use smothering her in our only blankets, giving her rough massages with melodic hands, and forcing her to drink bucketfuls of tea with cognac. The thing had nothing to do with the cold that forcibly snuck its way in through the corners of that humid shamble of a flat. One time she trembled so violently underneath the bedclothes that there was no choice but to call a doctor, who, in spite of the tremendous zeal and interest that he invested in the case, was unable to explain Bea's illness and prescribed pills that didn't help her one bit. When I discovered that with the arrival of the first warmth all her ills evaporated as if by magic, I stopped worrying myself over that mysterious illness that kept her chained to the bed throughout the entire winter.

- In any case, were it to snow some day, not anyone nor anything would be able to stop me from running down to the street to play with the snow-, she was accustomed to saying resolutely. And many times, I would catch her with her nose stuck to the windowpane overlooking the avenue staring at the clouds in wait of that imaginary snowfall.

Right now I would be incapable of remembering precisely how much time we spent together. I do, however, remember that on one fine day all understanding beyond the light tussle of the organs became impossible, my notes and books ended up in the garbage bin and the people who frequented the Rubio became inured to our bitter disputes. It was precisely at that moment that destiny chose to bring things to a boil: Bea was pregnant.

After a few days of circling the issue, I decided to convince Bea that we should reinvent our lives, begin again, restructure our coexistence and prepare a home fit for the needs of a child. But she refused to even hear mention of the idea.

- This city wasn't built for children or for birds - she said with finality, putting an end to the discussion.

What happened next, I can also not remember with precision. I think she called Mari, the model, and it was she who put her in touch with that quasi gypsy witch who in between ridicule and obscenities introduced a pin into the apex of her groin. Her heartrending wail and the diabolic laughter of that demonic matron stayed with me for a long time afterward. Not only that, to finance all that butchery, we had to sell the record player, all the things from Rochereau, Francó and what had up until then been my only indispensable luggage, my album of all of Bessie Smith's blues. It was like breaking with an entire era, or like saying goodbye to an old suit that had been a faithful companion 
during moments and scenes of transcendence. Yes, Bessie said goodbye and the farewell could not have been more in tune with that rainy day that seemed like it wanted to gather all the waters of the Mississippi and dump them on Betanzos Avenue, whose drains seemed powerless to absorb so much matted fluid, so much bile, so much black blood.

A long night, full of almost continual hemorrhaging and labored sobbing, put the final touches on the last day that, thanks to fear and uncertainty, we spent together. Bea, when she felt recovered, took her things and left.

- It always ends on the day when one must choose between birds or disaster - was the last thing she said to me as she closed the door.

It didn't take long for me to forget her since everything had ended long before we separated. But when my eyes caught sight of her paper butterflies, the philosophy books that she had deliberately left behind, or her careful arrangement of the furniture so that we could move comfortably throughout the room, I couldn't avoid thinking of her, remembering with every heartbeat how my memory was beginning to record gaps when I tried to sort certain details of our life together.

Once in a while news of her arrived through some friend that we had in common. That's how I learned that she had definitely dropped her studies, that she had met a tall, slim Andalusian named Pepe who made his living off of her. The Andalusian made her cruise the streets of the Fleming district; later she moved on to the lavish parties of fickle young men and when her body asked it of her, she found time to titillate the Americans that frequented the S'tones.

Today is like the day we first met. Madrid continues its unforgiveable path toward disaster and each time fewer birds remain. I think within ten or twenty years not one single bird will remain on the branches of the sad trees of Madrid. It was Nona who told me the terrible news: a black American who Bea had met at the Brother Wolf, and with whom she had made a date to go to Torrejón, had severed - on a stop that he made on the road to Barajas - her lower lip with a knife, cut off her eyebrows, her ears and her nostrils and then tossed her in a ditch. Bea hadn't wanted to explain to anyone what had happened to make the American commit such savagery. She has had no other recourse but to pack her bags and return to Senegal. She prefers to be stoned as a prostitute, in keeping with the custom of her tribe, than to endure the wintry cold besieging her impossible face.

Now, that favorite phrase of hers that I never understood to its full extent, has kept me company all day, on the bus, on the metro, through the main thoroughfares, as I chatted with my friends, drank tea or watched 
a dog urinate against a streetlight, that is to say, while I participated in the ceremony of vertigo and vortex that the big city imprints on all of our movements, all of our gestures. Now I know why Madrid is not a city for birds. 


\section{Poems by Luis Alberto Ambroggio}

The Grove 25 (2018-2020)

Here are two poems by American-Argentine writer and scholar Luis Alberto Ambroggio. Originally from Córdoba, Argentina, Ambroggio has lived in the Washington, DC area since 1967. His work explores the cross-cultural experience, social justice, the writer's craft and responsibility, among other topics.

Ambroggio is a Full Member of the North American Academy of the Spanish Language (ANLE). "Paisajes de Estados Unidos" (trans. View of the United States) and "Nómada del Silencio" (trans. Nomad of Silence) appear appropriately in the anthology titled Al pie de la Casa Blanca: Poetas hispanos de Washington, DC, edited by Luis Alberto Ambroggio and Carlos Parada Ayala (ANLE, New York, 2010).

Initially, these poems captured my attention when I taught heritage language students of Spanish at the United States Air Force Academy (Colorado). By teaching these verses, I aimed to honor the Spanish-speaking parents of my students. Another goal was my desire to highlight the Spanish language as a legitimate heir to the American experience.

The first poem embraces language and social justice. The second poem pivots from social protest to the meta-literary and self-reflexive. The dedication to Hawad, representative of Tuareg literature of the Berber, illuminates the title and the searching life of the poet. The reader experiences the poet wrestling with writing and placing himself and his work within literary, cultural and intellectual traditions.

Today I find these poems as relevant as I did when I first encountered them due to the current cultural and linguistic tensions in the United States. Also, the waning respect for the literary tradition by the American people amplifies the value of Ambroggio's poems in 2020. 


\section{View of the United States}

If every brick could speak;

If every bridge could speak;

If the parks, plants, and flowers had a voice;

If every block of pavement could speak,

They would speak in Spanish.

If the towers, the roofs,

The air conditioners could speak;

If the churches, airports, and factories had a voice,

They would speak in Spanish.

If every drop of sweat flourished with a name, They would not be stale names, rather Sánchez, González, García, Rodríguez or Peña.

But they cannot speak.

They are mere hands, labor, scars,

That for now remain silent. 


\section{Nomad of Silence}

\section{To Hawad, voice of the Tuareg}

Soon the bridges will collapse.

The rivers, the seas will swallow the earth.

We will beg for, if we can, air for the eyes

winds for the mute sands.

And what can I do with the tides with these islands made of black rocks with the thin clouds that glide by carrying their loads of gray sadness.

And if everything were to become a desert before marching to the dunes, nomad of silence, if Keats were to hear me, if even the wise Jefferson could listen, I would shout at them with the obstinate rumor of the wind

"I would rather write wandering than to write in desperation."

Washington, DC, 2003.

Sheri Spaine-Long has been Professor of Spanish studies at the University of Alabama at Birmingham, and Chair of its Spanish department. Prof. Spaine-Long has specialized in language teaching and learning, with a stress on the Spanish language, and she is an award-winning teacher who has been appointed to various positions in several academic institutions in the US. She is currently the Executive Director at The American Association of Teachers of Spanish and Portuguese (AATSP). Prof. Spaine-Long is the author of several publications and conference papers focusing on Madrid in Spanish prose as well as the development of contentbased instructional materials for the language classroom, such as the worldrenown Nexos series of manuals for teaching Spanish. 
